\title{
Spring diet composition of Rainbow Trout, Oncorhynchus mykiss (Walbaum, 1792) in the Urederra River (Spain)
}

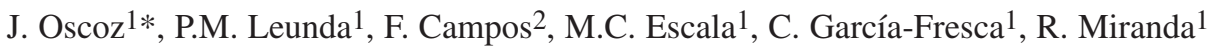 \\ ${ }_{1}^{1}$ Departamento de Zoología y Ecología, Facultad de Ciencias, Universidad de Navarra, Apdo. 177, E-31080 Pamplona, Spain. \\ 2 Universidad Europea Miguel de Cervantes, C/Padre Julio Chevalier, E-47012, Valladolid, Spain.
}

\begin{abstract}
This study describes the diet composition of 42 rainbow trout, Oncorhynchus mykiss (Walbaum, 1792) (90-480 mm TL), captured in May 1995 in the Urederra River (North of Spain). Rainbow trout of all sizes fed mainly on midge (adults, larvae and pupae), but there were some differences in the feeding habits of small and large fish. We found that as the trout grew larger terrestrial prey became the most important food item. Rainbow trout avoided Leuctridae and showed some preference for Ephemeroptera, Diptera larvae and Nemouridae larvae. Native fish predation and exploitation of the same trophic resources in the Urederra River, could negatively affect native fishes, such as European minnow, Phoxinus phoxinus L., 1758 or brown trout, Salmo trutta L., 1758.
\end{abstract}

Keywords : Oncorhynchus mykiss, rainbow trout, diet composition, prey selection, Urederra River, Spain.

\section{Introduction}

Rainbow trout, Oncorhynchus mykiss (Walbaum, 1792), occur naturally in the eastern Pacific Ocean, and in fresh water they exist mainly in the west of the Rocky Mountains from northwest Mexico to the Kuskokwim River, Alaska (Jonsson et al. 1993). The species was first introduced in Spain in the late $19^{\text {th }}$ century (Elvira 1995) and it is still present in all Spanish basins (Doadrio 2001), especially in areas close to fish farms, from where specimens frequently escape (Carss 1990). The introduction of rainbow trout can alter native fish populations through predation, competition for food or territorial space, acting as carriers of different diseases and through destruction of earlier trout spawning beds (Landergren 1999).

Knowledge of the interaction between exotic and native species is necessary for adequate aquatic management. In this way, diet studies constitute an important tool (Neveu 1979), because trophic interaction between species (competition and predation) is an important mechanism in determining the distribution of

\footnotetext{
* Corresponding author :

E-mail: joscoz@alumni.unav.es
}

aquatic communities (Lammens et al. 1992, Declerck et al. 2002).

The aim of this study is to describe the diet composition of rainbow trout in the Urederra River, as a first step in evaluating the interaction between rainbow trout and native fishes. The possible interaction will be discussed in comparison with previous works describing the feeding preferences of brown trout, Salmo trutta L., 1758 (Oscoz et al. 2000, Oscoz 2003) and European minnow, Phoxinus phoxinus (L., 1758) (Oscoz et al. 2001) in the nearby Larraun River.

\section{Study area}

Our study was carried out in the Urederra River (Navarra, North of Spain), a tributary of the Ega River (Ebro basin) (Fig. 1). The Urederra River has a catchment area of $319 \mathrm{~km}^{2}$ and a total length of $20 \mathrm{~km}$. Its altitude ranges from $750 \mathrm{~m}$ at the source to $450 \mathrm{~m}$ at its confluence with the Ega River, flowing mainly over a limestone watershed. Bedrock, boulders and cobbles dominate the river substrate, whereas the riparian vegetation consists mainly of alders (Alnus glutinosa) and willows (Salix alba and S. purpurea).

Whilst Brown trout (Salmo trutta L., 1758) and Eu-

Article available at http://www.limnology-journal.org or http://dx.doi.org/10.1051/limn/2005003 


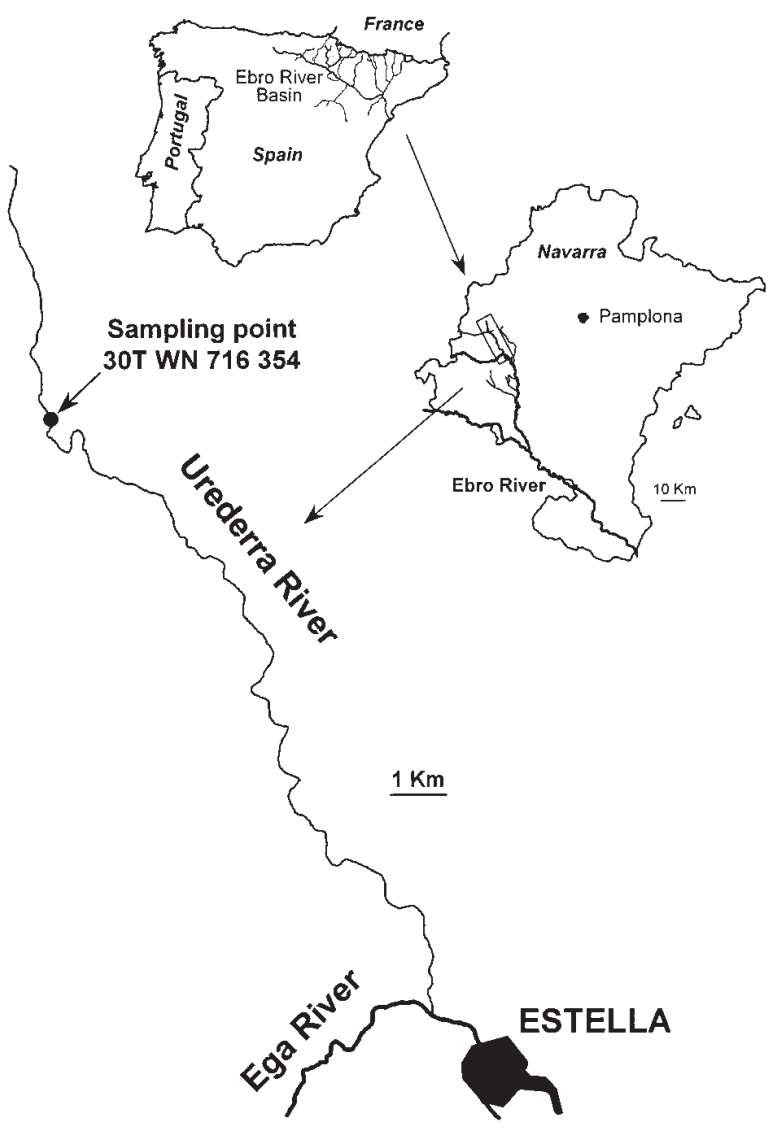

Fig. 1. Maps locating the Ebro River Basin and Navarra in the Iberian Peninsula (top left), the Urederra River in Navarra (right), and the sampling point location in the Urederra River.

ropean minnow (Phoxinus phoxinus (L., 1758)) occur with the rainbow trout in the studied river stretch (Oscoz et al. 1999), the rest of the river contains French nase (Chondrostoma miegii Steindachner, 1866), Graells barbel (Barbus graellsii Steindachner, 1866), Stone loach (Barbatula barbatula (L., 1758)), Gudgeon (Gobio gobio (L., 1758)) and eel (Anguilla anguilla (L., 1758)) (Campos et al. 1997).

There is an aquaculture farm in the upper stretch of the Urederra River where species frequently scape into the river. This farm is dedicated exclusively to cultivating rainbow trout up to a size of $60-80 \mathrm{~g}$. Although the escaped rainbow trout have been reported to breed to maturity, there is no evidence of successful reproduction. The studied river stretch in base flow has an average depth of $34 \mathrm{~cm}$ and a mean water surface width of $9 \mathrm{~m}$, and the river bed is dominated by rubble and cobble (64-256 mm size, Simonson et al. (1994)).

\section{Material and methods}

Rainbow trout were captured by electrofishing surveys carried out in a 100-m-length river stretch in May 1995. A detailed description of the river stretch characteristics and electrofishing surveys are in Campos et al. (1997). Rainbow trout were preserved in ice, but not frozen. In the laboratory, the stomachs were removed and preserved in a $4 \%$ formalin solution. The stomach content was identified under a magnifying microscope (x7-45). The stomach contents of 42 rainbow trout (90-480 mm total length (TL)) were analyzed. Fish age determination was done by scale annuli reading and validated with length-frequency histograms. Age classes 1 (<120 mm TL), 2 (120-170 mm TL) and >2 $(>170 \mathrm{~mm}$ TL) were identified.

Four prey groups were identified : plant material, fishes, terrestrial invertebrates and aquatic invertebrates. When possible, aquatic invertebrates were identified to family level, terrestrial invertebrates to order level and fishes to species level. Because of the low occurrence and volume of plant material present in the stomachs the abundance of plant material was not quantified, and only the number of stomachs in which it appeared was noted.

In animal prey items, the frequency of occurrence of a given prey type is defined as the number of stomachs in which that prey occurs, expressed as a frequency of the total number of stomachs in which prey are present (Hynes 1950). The relative abundance of a prey (or contribution to the stomach contents) is defined as the percentage of total stomach contents in all predators comprised by that given prey. In mathematical terms, the percentage occurrence $\left(\% F_{i}\right)$ and the percentage abundance $\left(\% A_{i}\right)$ of prey type $i$ can be described by the equations :

$$
\% F_{i}=\left(N_{i} / N\right) \times 100 \quad \% A_{i}=\left(\sum S_{i} / \sum S_{t}\right) \times 100
$$

where, $N_{i}$ is the number of predators with prey $i$ in their stomach, $N$ is the total number of predators with stomach contents, $S_{i}$ the stomach content (number) composed by prey $i$, and $S_{t}$ the total stomach content of all stomachs in the entire sample (Amundsen et al. 1996). The differences in diet composition between age classes were analyzed with a $\chi^{2}$ test (significance $\mathrm{P}<0.05)$.

Trophic diversity was calculated according to Shannon's index $\left(H^{\prime}=-\sum S_{i} \log _{2} S_{i}\right)$. Furthermore, in order to evaluate specialization in the diet of rainbow trout evenness index $\left(E=H^{\prime} / H^{\prime}\right.$ max $)$ was determined, considering that values close to zero mean a stenophagous diet and those closer to one a more euryphagous diet. 
Feeding strategy diagrams were constructed following the Costello (1990) method with the modifications suggested by Amundsen et al. (1996). These diagrams are based on a two-dimensional representation, where each point represents the frequency of occurrence $(\% \mathrm{Fi})$ and the prey-specific abundance $\left(\% P_{i}\right.$ $\left.=\left(\sum S_{i} / \sum S_{t i}\right)^{\cdot 100}\right)$, where $P_{i}$ is the prey-specific abundance of prey $i$, and $S_{t i}$ is the total stomach content in only those predators with prey $i$ in their stomach.

Prey selection was also analyzed, comparing diet composition with benthic macroinvertebrates present in the river stretch. A benthos sample was collected using a Surber net with $0.1-\mathrm{mm}$ mesh size in four replicates of $0.25 \mathrm{~m}^{2}$. The sample was preserved at the capture site with $4 \%$ formalin solution. In the laboratory all the macroinvertebrates were counted and classified. Prey selection was quantified using Savage's index (Savage 1931) $W_{i}=A_{i} / D_{i}$, where $A_{i}$ is the relative abundance of prey $i$ in the stomach content, and $D_{i}$ is the relative availability of this resource in the river. The values close to 1 in $W_{i}$ mean no selection of prey $i$, and values lower and greater than 1 show avoidance (negative preference) and selection (positive preference) respectively. This index was chosen because it is more objective than other similar indices, and it is possible to verify its statistical significance with a $\chi^{2}$ test (Manly et al. 1993).

\section{Results}

A total of 42 fishes were analyzed. Three rainbow trout had empty stomachs and were not analyzed further. In the other stomachs analyzed, 4203 preys were identified (Table 1). These belonged mainly to terrestrial Diptera and aquatic Chironomidae (larvae and pupae). One specimen (391 mm TL) fed only on fish (35 minnows) and another specimen (480 mm TL) fed only on snails (67 Lymnaeidae). Three age $>2$ individuals presented plant material in their stomach contents.

Relative abundance of prey items differed significantly between different age classes $\left(\chi^{2}=563.3,16 \mathrm{df}\right.$, $\mathrm{P}<0.001)$. Older specimens increased the use of terrestrial invertebrates, until aquatic and terrestrial prey were equally consumed (Fig. 2). With reference to aquatic prey, the use of Ephemeroptera and Diptera larvae decreased as trout grew older, but the use of Chironomidae pupae increased (Table 1). The mean number of prey per stomach was higher in the older trout (Age 1: 65.0 prey per stomach, Age $2: 118.8$, Age $>2: 141.3$ ).

Trophic diversity and evenness indices decreased as trout grew larger (Table 1), suggesting less eurypha- gous feeding behavior. This feeding strategy change was confirmed by the feeding strategy plots (Fig. 3).

On the other hand, benthic prey selection was similar between different age classes (Table 2). All trout positively selected Baetidae, Heptageniidae, Nemouridae, Rhyacophilidae, Stratiomyidae and Nematoda, whereas Leuctridae was avoided. Furthermore, age 2 and age 1 trout positively selected Simuliidae, while age 2 and age $>2$ trout positively selected Chironomidae.

\section{Discussion}

The diet of rainbow trout in Urederra River includes benthic invertebrates, fishes and terrestrial invertebrates. A similar diet composition has been described in e.g., American lakes (Rabe 1967), Australian rivers (Pidgeon 1981), an Argentinean reservoir (Ferriz 1988) and Hawaiian streams (Kido et al. 1999). Different works have highlighted the opportunistic feeding behaviour of rainbow trout (Artigas et al. 1984, Gibson 1988, Ferriz 1994), identical to other salmonids (Vignes 1998), that modify their diet depending on prey availability. For this reason, the high consumption of Chironomidae pupae and terrestrial Diptera could be explained by the fact that the study period coincided with the highest emergence period of these prey, when usually they are very abundant and readily available.

Diet variation in fishes is related to prey availability, their accessibility and the risk of predation (Eggers 1982, Greenberg et al. 1997). As a result bigger prey that are easier to capture or with high energetic value are consumed more. Since terrestrial prey are easier to detect and have lower evasive ability (McLaughlin et al. 1994), during their emergence they become an important and valuable prey for visual predators such as rainbow trout. Nevertheless, terrestrial prey consumption is also related to other factors like topography, riparian vegetation or weather (Artigas et al. 1984, Vollestad \& Andersen 1985, Cavalli et al. 1997).

The presence of European minnow in larger rainbow trout's (Age >2) stomachs confirms their predation on small native fishes. The apparently high consumption of Nematoda may not be real since some could be trout parasites (Molloy et al. 1995, Brotheridge et al. 1998, Byrne et al. 2002). Further studies would be necessary to determine whether their presence is due to real active consumption or parasitism.

The point distribution of the feeding strategy plots and the decrease of the trophic diversity and evenness indexes suggested less euryphagous feeding behaviour 
as trout grew larger. The positioning of the points mainly in the lower part of the feeding strategy plots show that the average contribution of the prey items to the stomach contents was low, indicating a generalized feeding strategy (Amundsen et al. 1996). However, some prey items contribute more to the stomach contents as trout grow larger, i.e. they became less generalist.

Diet variation as fishes grow is well documented in

Table 1. Diet composition of rainbow trout in the Urederra River (May 1995). The data are expressed as percentage of occurrence (\%Fi) and relative abundance (\%Ai). (L: Larvae; P: Pupae; I: Adult). Values of trophic diversity (H') and evenness index (E) are shown.

\begin{tabular}{|c|c|c|c|c|c|c|c|c|}
\hline \multirow{3}{*}{ AQUATIC INVERTEBRATES } & \multicolumn{2}{|c|}{ Age 1} & \multicolumn{2}{|c|}{ Age 2} & \multicolumn{2}{|c|}{ Age $>2$} & \multicolumn{2}{|c|}{ Total } \\
\hline & \multirow[t]{2}{*}{$\% F_{i}$} & \multirow[t]{2}{*}{$\% A_{i}$} & \multirow[t]{2}{*}{$\% F_{i}$} & \multirow[t]{2}{*}{$\% A_{i}$} & \multirow[t]{2}{*}{$\% F_{i}$} & \multirow[t]{2}{*}{$\% A_{i}$} & \multirow[t]{2}{*}{$\% F_{i}$} & \multirow[t]{2}{*}{$\% A_{i}$} \\
\hline & & & & & & & & \\
\hline Hidracarina & 7.69 & 0.12 & - & - & 16.67 & 0.12 & 7.69 & 0.07 \\
\hline Nematoda & 61.54 & 15.98 & 92.86 & 7.64 & 58.33 & 5.96 & 71.79 & 8.64 \\
\hline Gammaridae & 15.38 & 0.24 & 7.14 & 0.06 & - & - & 7.69 & 0.07 \\
\hline Isopoda & - & - & - & - & 8.33 & 0.06 & 2.56 & 0.02 \\
\hline Lymnaeidae & - & - & - & - & 8.33 & 3.95 & 2.56 & 1.59 \\
\hline Baetidae & 84.62 & 18.11 & 00.00 & 7.52 & 75.00 & 3.36 & 87.18 & 7.97 \\
\hline Heptageniidae & 69.23 & 4.85 & 57.14 & 1.62 & 50.00 & 2.60 & 58.97 & 2.66 \\
\hline Leuctridae & 7.69 & 0.12 & - & - & - & - & 2.56 & 0.02 \\
\hline Nemouridae & 84.62 & 2.37 & 57.14 & 1.56 & 41.67 & 0.47 & 61.54 & 1.28 \\
\hline Perlodidae & - & - & 7.14 & 0.06 & - & - & 2.56 & 0.02 \\
\hline Hydroptilidae & 15.38 & 0.36 & 7.14 & 0.06 & 8.33 & 0.06 & 10.26 & 0.12 \\
\hline Limnephilidae & - & - & - & - & 33.33 & 0.24 & 10.26 & 0.10 \\
\hline Rhyacophilidae (L) & 15.38 & 0.59 & 64.29 & 0.90 & 33.33 & 0.35 & 38.46 & 0.62 \\
\hline Rhyacophilidae (P) & - & - & 7.14 & 0.06 & 8.33 & 0.06 & 5.13 & 0.05 \\
\hline Chironomidae (L) & 84.62 & 13.25 & 85.71 & 3.49 & 66.67 & 1.95 & 79.49 & 4.83 \\
\hline Chironomidae $(P)$ & 69.23 & 11.72 & 00.00 & 20.87 & 75.00 & 27.49 & 82.05 & 21.70 \\
\hline Limoniidae & - & - & 21.43 & 0.18 & 8.33 & 0.06 & 10.26 & 0.10 \\
\hline Simuliidae (L) & 69.23 & 12.07 & 85.71 & 5.05 & 58.33 & 2.42 & 71.79 & 5.40 \\
\hline Simuliidae $(P)$ & 23.08 & 1.18 & 35.71 & 0.48 & - & - & 20.51 & 0.43 \\
\hline Stratiomyidae & 15.38 & 0.71 & 28.57 & 0.66 & 16.67 & 0.24 & 20.51 & 0.50 \\
\hline Dytiscidae (I) & 7.69 & 0.12 & 7.14 & 0.06 & - & - & 5.13 & 0.05 \\
\hline Haliplidae (I) & - & - & 7.14 & 0.06 & - & - & 2.56 & 0.02 \\
\hline TOTAL AQUATIC INV. & 00.00 & 81.78 & 00.00 & 50.33 & 91.67 & 49.38 & 97.44 & 56.27 \\
\hline \multicolumn{9}{|l|}{ FISHES } \\
\hline Phoxinus phoxinus & - & - & - & - & 8.33 & 2.06 & 2.56 & 0.83 \\
\hline \multicolumn{9}{|c|}{ TERRESTRIAL INVERTEBRATES } \\
\hline Diptera & 69.23 & 17.40 & 92.86 & 48.59 & 75.00 & 46.90 & 79.49 & 41.64 \\
\hline Coleoptera & 15.38 & 0.47 & 42.86 & 0.66 & 50.00 & 0.65 & 35.90 & 0.62 \\
\hline Lepidoptera (L) & 7.69 & 0.12 & 14.29 & 0.12 & 16.67 & 0.12 & 12.82 & 0.12 \\
\hline Molusca & - & - & - & - & 8.33 & 0.06 & 2.56 & 0.02 \\
\hline Formicidae & 7.69 & 0.12 & 14.29 & 0.24 & 33.33 & 0.35 & 17.95 & 0.26 \\
\hline Hemiptera & - & - & 7.14 & 0.06 & 8.33 & 0.06 & 5.13 & 0.05 \\
\hline Non-identified Insecta & 7.69 & 0.12 & - & - & 41.67 & 0.41 & 15.38 & 0.19 \\
\hline TOTAL TERRESTRIAL INV. & 69.23 & 18.22 & 00.00 & 49.67 & 75.00 & 48.55 & 82.05 & 42.90 \\
\hline \multicolumn{9}{|l|}{ PLANT MATERIAL } \\
\hline Plant material & - & - & - & - & 25.00 & - & 7.69 & - \\
\hline Number of stomachs & \multicolumn{2}{|c|}{13} & \multicolumn{2}{|c|}{14} & \multicolumn{2}{|c|}{12} & \multicolumn{2}{|c|}{39} \\
\hline Total number of preys & \multicolumn{2}{|c|}{845} & \multicolumn{2}{|c|}{1663} & \multicolumn{2}{|c|}{1695} & & \\
\hline$H^{\prime}$ & & & & & & & & \\
\hline$E$ & & & & & & & & \\
\hline
\end{tabular}




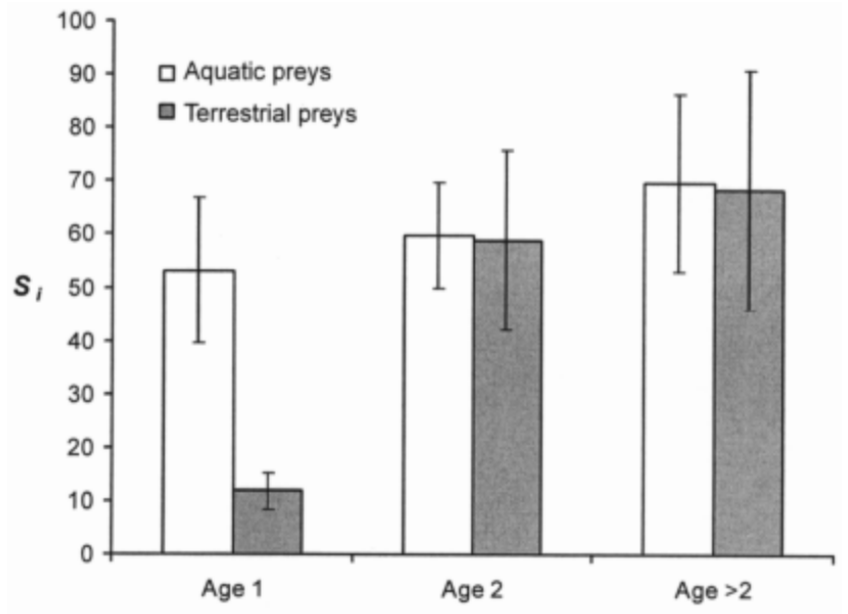

Fig. 2. The mean number of prey (Si) consumed by rainbow trout of different age classes in the Urederra River (May 1995). Error bars indicate standard error.
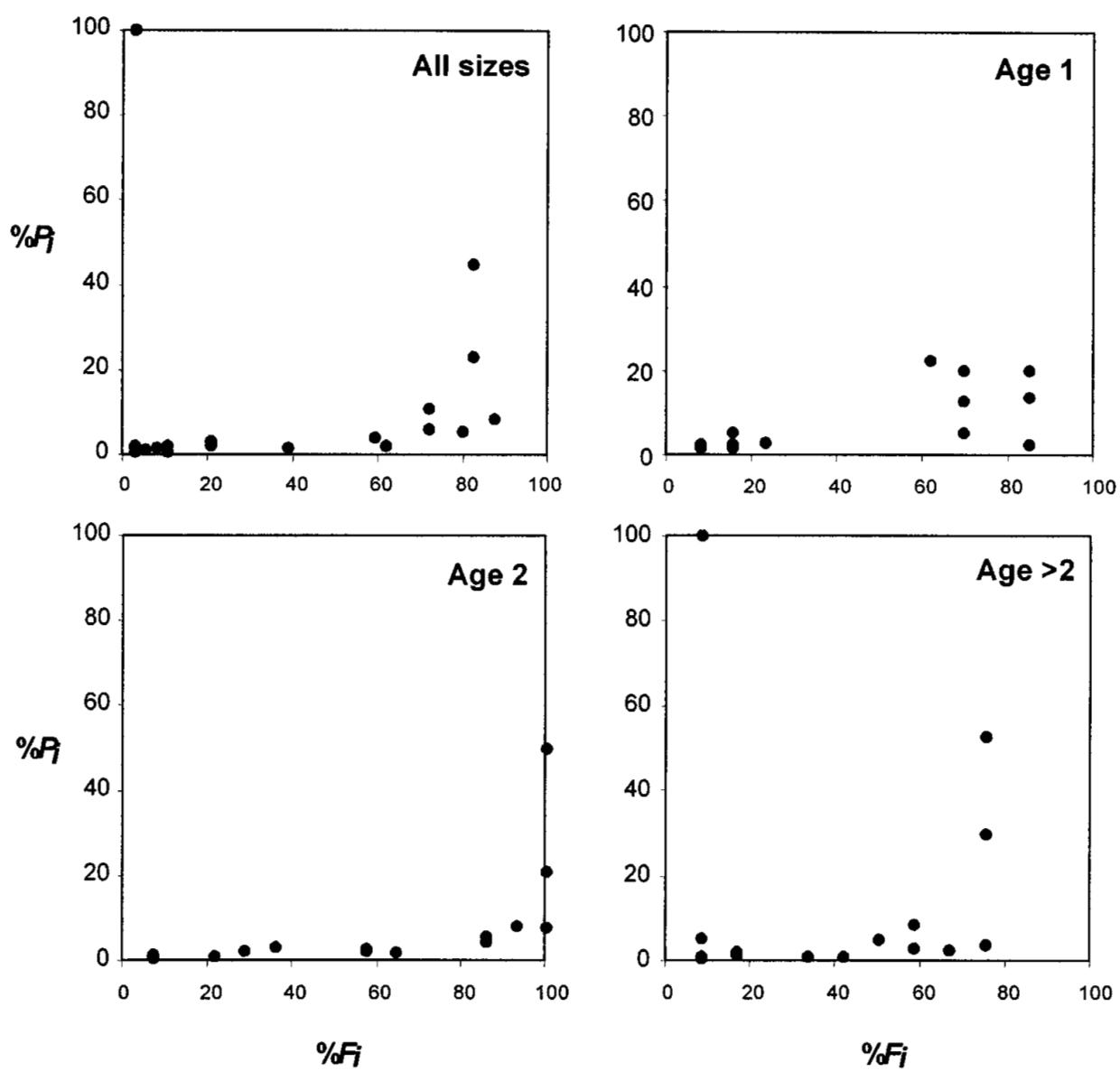

Fig. 3. Feeding strategy plots of the different rainbow trout age classes in the Urederra River (May 1995). Points represent different prey items. 
both rainbow trout and other salmonids (Tippets \& Moyle 1978, Ferriz 1994, Oscoz et al. 2000). In the Urederra River age 1 trout had a more benthic diet than older trout, probably because feeding at the bottom of the river implies less risk from predators than feeding at the surface (Vollestad \& Andersen 1985, Haugen \& Rygg 1996). In older trout there was a higher consumption of terrestrial invertebrates, indicating that they mainly feed on drifting invertebrates. Elliott (1967) suggested that these differences in diet composition between age classes could reduce trophic competition, somewhat facilitated by habitat segregation. This could be the explanation why smaller trout use prey not available to older trout (Jonsson \& Gravem 1985). Likewise, Mollusca and fishes were only used by older trout because their bigger size requires a bigger mouth size, and a greater swimming ability in the case of fish predation (Easton \& Orth 1992, Keeley \&
Grant 1997). This also allows older trout to have a bigger number of potential preys. Furthermore, the larger stomach size in older trout would allow ingesting a higher number of preys (Neveu \& Thibault 1977).

Observed prey selection in analyzed rainbow trout would be related to prey availability and its energetic value (Vinyard 1980). Those prey easier to capture or with higher energetic value (such as Ephemeroptera, Diptera and Trichoptera) would be consumed more (Penczak et al. 1984), while those of lower energetic value, smaller or those that can camouflages themselves or hide under the substratum (e.g. Plecoptera) would be difficult to detect (Ware 1973, Rajasilta \& Vuorinen 1983, Rincón \& Lobón-Cerviá 1999), and as a result be consumed less.

Our results indicate that rainbow trout can affect autochthonous fish populations, like brown trout and Eu-

Table 2. Prey selection by rainbow trout in the Urederra River (May 1995). \%Di: availability, \%Ai: relative abundance, Wi: Savage index. ns: $\mathrm{P}>0.05 ; *: \mathrm{P}<0.05$; **: $\mathrm{P}<0.01$. The significance levels were obtained applying Bonferroni's correction ((/number of categories).

\begin{tabular}{|c|c|c|c|c|c|c|c|c|c|c|}
\hline & \multirow{2}{*}{$\begin{array}{c}\text { Benthos } \\
\% D_{i}\end{array}$} & \multicolumn{2}{|c|}{ Age 1} & & \multicolumn{2}{|c|}{ Age 2} & & \multicolumn{2}{|c|}{ Age $>2$} & \\
\hline & & $\% A_{i}$ & $W_{i}$ & & $\% A_{i}$ & $W_{i}$ & & $\% A_{i}$ & $W_{i}$ & \\
\hline Hidracarina & 0.18 & 0.14 & 0.809 & ns & - & 0.000 & ns & 0.24 & 1.336 & ns \\
\hline Gammaridae & 0.57 & 0.29 & 0.512 & ns & 0.12 & 0.211 & ns & - & 0.000 & ns \\
\hline Isopoda & - & - & - & & - & - & & 0.12 & - & \\
\hline Lymnaeidae & - & - & - & & - & - & & 8.00 & - & \\
\hline Baetidae & 2.54 & 22.14 & 8.724 & $\star \star$ & 14.93 & 5.884 & $\star \star$ & 6.81 & 2.683 & $\star *$ \\
\hline Heptageniidae & 1.46 & 5.93 & 4.064 & $* *$ & 3.23 & 2.209 & $\star \star *$ & 5.26 & 3.601 & $* *$ \\
\hline Leuctridae & 40.52 & 0.14 & 0.004 & $* *$ & - & 0.000 & $\star \star$ & - & 0.000 & $* *$ \\
\hline Nemouridae & 0.14 & 2.89 & 20.645 & $* *$ & 3.11 & 22.157 & $\star *$ & 0.96 & 6.817 & $* *$ \\
\hline Perlodidae & - & - & - & & 0.12 & - & & - & - & \\
\hline Hydroptilidae & - & 0.43 & - & & 0.12 & - & & 0.12 & - & \\
\hline Limnephilidae & - & - & - & & - & - & & 0.48 & - & \\
\hline Rhyacophilidae & 0.20 & 0.72 & 3.564 & * & 1.91 & 9.415 & $* *$ & 0.84 & 4.119 & ** \\
\hline Chironomidae & 27.58 & 30.54 & 1.107 & ns & 48.39 & 1.755 & $* *$ & 59.62 & 2.162 & $\star \star$ \\
\hline Limoniidae & 0.05 & - & 0.000 & ns & 0.36 & 6.740 & $\star *$ & 0.12 & 2.247 & ns \\
\hline Simuliidae & 5.26 & 16.21 & 3.079 & $\star \star$ & 10.99 & 2.088 & $* *$ & 4.90 & 0.930 & ns \\
\hline Stratiomyidae & 0.05 & 0.87 & 16.328 & $\star *$ & 1.31 & 24.713 & ** & 0.48 & 8.987 & $* *$ \\
\hline Dytiscidae (A) & 0.01 & 0.14 & 9.978 & ns & 0.12 & 8.238 & ns & - & 0.000 & ns \\
\hline Haliplidae (A) & - & - & - & & 0.12 & - & & - & - & \\
\hline Nematoda & 0.53 & 19.54 & 37.075 & $\star *$ & 15.17 & 28.794 & $* *$ & 12.07 & 22.899 & $\star *$ \\
\hline Other invertebrates & 20.91 & - & 0.000 & $\star \star$ & - & 0.000 & $* *$ & - & 0.000 & $\star \star$ \\
\hline
\end{tabular}


ropean minnow, because it is a predator of smaller specimens. In addition, previous works in the nearby Larraun River showed that European minnows and 0+ brown trout use the same prey items with a positive preference for Chironomids (Oscoz et al. 2000, 2001, Oscoz 2003). This competition could be the explanation for the low density of European minnow and $0+$ brown trout observed in this reach by Oscoz et al. (1999). Nevertheless, a more precise study would be necessary in order to quantify the effect of rainbow trout on autochthonous fish populations.

\section{Acknowledgments}

Authors appreciate the comments made by two anonymous referees, and the language corrections made by Dave Ndlovu.

\section{References}

Amundsen P.A., Gabler H.M. \& Staldvik F.J. 1996. - A new approach to graphical analysis of feeding strategy from stomach contents data - modification of the Costello (1990) method. J. Fish Biol., 48, 607-614.

Artigas J.N., Campusano E. \& González U. 1984. - Contribución al conocimiento de la biología y hábitos alimentarios de Salmo gairdneri (Richardson, 1836) en lago Naja (Chile). Gayana Zool., 49, 3-29.

Brotheridge R.M., Newton K.E. \& Evans S.W. 1998. - Presence of a parasitic nematode (Eustrongylides sp.) in brown trout (Salmo trutta) from a heavy metal contaminated aquatic ecosystem. Chemosphere, 37, 2921-2934.

Byrne C.J., Holland C.V., Poole R. \& Kennedy C.R. 2002. - Comparison of the macroparasite communities of wild and stocked brown trout (Salmo trutta L.) in the west of Ireland. Parasitology, $124,435-445$.

Campos F., Lekuona J.M., García-Fresca C., Oscoz J., Miranda R. De La Riva C. \& Escala M.C. 1997. - Annual variation of the fish community composition in the Urederra River (Navarra, Spain). Limnetica, 13, 25-29.

Carss D.N. 1990. - Concentrations of wild and escaped fishes immediately adjacent to fish farm cages. Aquaculture, 90, 29-40.

Cavalli L., Chappaz R., Bouchard P. \& Brun G. 1997. - Food availability and growth of the brook trout, Salvelinus fontinalis (Mitchill), in a French Alpine lake. Fish. Manage. Ecol., 4, 167-177.

Costello M.J. 1990. - Predator feeding strategy and prey importance : a new graphical analysis. J. Fish Biol., 36, 261-263.

Declerck S., Louette G., De Bio T. \& De Meester L. 2002. - Patterns of diet overlap between populations of non-indigenous and native fishes in shallow ponds. J. Fish Biol., 61, 1182-1197.

Doadrio I. 2001. - Atlas y libro rojo de los peces continentales de España. Mus. Nac. Cienc. Nat. (CSIC), Ministerio de Medio Ambiente, Madrid, $364 \mathrm{p}$

Easton R.S. \& Orth D.J. 1992. - Ontogeneic diet shifts of age 0 smallmouth bass (Micropterus dolomeu Lacepede) in the New River, West Virginia, USA. Ecol. Freshwat. Fish, 1, 86-98.

Eggers D.M. 1982. - Planktivore preference by prey size. Ecology, $63,381-390$

Elliott J.M. 1967. - The food of trout (Salmo trutta) in a Dartmoor stream. J. Appl. Ecol., 4, 60-71.
Elvira B. 1995. - Freshwater fishes introduced in Spain and relationships with autochthonous species. Pages 262-265 In : Protection of Aquatic Biodiversity. Procc. World Fisheries Congress, Theme 3, Philipp D.P., Epifanio J.M., Marsden J.E. \& Claussen J.E. (eds.). Oxford \& IBHPubl. Co. Pvt. Ltd., New Dehli.

Ferriz R.A. 1988. - Relaciones tróficas de trucha marrón, Salmo fario Linné, y trucha arco iris, Salmo gairdneri Richardson, (Osteichthyes, Salmoniformes) en un embalse norpatagónico. Stud. Neotrop. Fauna Environ., 23, 123-131.

Ferriz R.A. 1994. - Algunos aspectos de la dieta de cuatro especies ícticas del río Limay (Argentina). Rev. Ictiol., 2/3, 1-7.

Gibson J.R. 1988. - Mechanisms regulating species composition, population structure and production of stream salmonids : a review. Pol. Arch. Hydrobiol., 35, 469-495.

Greenberg L.A., Bergman E. \& Eklov A.G. 1997. - Effects of predation and intraspecific interactions on habitat use and foraging by brown trout in artificial streams. Ecol. Freshwat. Fish, 6, 16-26.

Haugen T.O. \& Rygg T.A. 1996. - Food- and habitat-segregation in sympatric grayling and brown trout. J. Fish Biol., 49, 301-318.

Hynes H.B.N. 1950. - The food of fresh-water sticklebacks (Gasterosteus aculeatus and Pygosteus pungitius), with a review of methods used in studies of the food of fishes. J. Anim. Ecol., 19, 3658 .

Jonsson B. \& Gravem F.R. 1985. - Use of space and food by resident and migrating brown trout, Salmo trutta. Environ. Biol. Fish., 14 281-293.

Jonsson N., Jonsson B., Hansen L.P. \& Aass P. 1993. - Coastal moement and growth of domesticated rainbow trout (Onchorhynchus mykiss (Walbaum)) in Norway. Ecol. Freshwat. Fish, 2, 152-159.

Keeley E.R. \& Grant J.W.A. 1997. - Allometry of diet selectivity in juvenile atlantic salmon (Salmo salar). Can. J. Fish. Aquat. Sci., 54, 1894-1902.

Kido M.H., Heacock D.E. \& Asquith A. 1999. - Alien rainbow trout (Oncorhynchus mykiss) (Salmoniformes : Salmonidae) diet in Hawaiian streams. Pac. Sci., 53 : 242-251.

Lammens E.H.R.R., Frank-Landman A., McGillavry P.J. \& Vlink B. 1992. - The role of predation and competition in determining the distribution of common bream, roach and white bream in Dutch eutrophic lakes. Environ. Biol. Fish., 33, 195-205.

Landergren P. 1999. - Spawning of anadromous rainbow trout, Oncorhynchus mykiss (Walbaum) : a threat to sea trout, Salmo trutta L., populations? Fish. Res., 40, 55-63.

Manly B., McDonand L. \& Thomas D. 1993. - Resource selection by animals. Statistical design and analysis for field studies. Chapman \& Hall, London, 177 p.

McLaughlin R.L., Grant J.W.A. \& Kramer D.L. 1994. - Foraging movements in relation to morphology, water-column use and diet of recently emerged brook trout (Salvelinus fontinalis) in Stillwater pools. Can. J. Fish. Aquat. Sci., 51, 268-279.

Molloy S., Holland C. \& Poole R. 1995. - Metazoan parasite community structure in brown trout from two lakes in western Ireland. J. Helminthol., 69, 237-242.

Neveu A. 1979. - Les problèmes posés par l'étude de l'alimentation naturelle des populations sauvages de poissons. Bull. Cent. Etud. Rech. sc., Biarritz, 12, 501-512.

Neveu A. \& Thibault M. 1977. - Comportament alimentaire d'une population sauvage de Truite fario (Salmo trutta L.) dans un ruisseau des Pyrénées atlantiques, Le Lissuraga. Ann. Hydrobiol., 8, $111-128$. 
Oscoz J. 2003. - Estudio del Río Larraun (Navarra) : Calidad de sus aguas y análisis de la comunidad piscícola. Ph.D. Tesis, University of Navarra, $383 \mathrm{p}$.

Oscoz J., Campos F., Escala M.C., Miranda R., Lekuona J.M., García-Fresca C. \& De La Riva C. 1999. - Efecto de una piscifactoría sobre la fauna de macroinvertebrados y peces fluviales del río Urederra (Navarra, España). Bol. R. Soc. Esp. Hist. Nat. (Sec. Biol.), 95, 109-115.

Oscoz J., Escala M.C. \& Campos F. 2000. - La alimentación de la trucha común (Salmo trutta L. 1758) en un río de Navarra (N. España). Limnética, 18, 29-35.

Oscoz J., Campos F. \& Escala M.C. 2001. - Alimentación del piscardo (Phoxinus phoxinus) en un río del Norte de España. Ecologia, 15, 285-291.

Penczak T., Kusto E., Kryzanowska D., Molinski M. \& Suszycka E. 1984. - Food consumption and energy transformations by fish populations in two small lowland rivers in Poland. Hydrobiologia, 108, 135-144.

Pidgeon R.W.J. 1981. - Diet and growth of rainbow trout, Salmo gairdneri Richardson, in two streams on the New England Tableland, New South Wales. Aust. J. Marine Freshwater Res., 32, 967-974.

Rabe F.W. 1967. - Age and growth of rainbow trout in four alpine lakes. Northwest Sci., 41, 12-22.

Rajasilta M. \& Vuorinen I. 1983. - A field study of prey selection in planktivorous fish larvae. Oecologia, 59, 65-68.
Rincón P.A. \& Lobón-Cerviá J. 1999. - Prey-size selection by brown trout (Salmo trutta L.) in a stream in northern Spain. Can. J. Zool., 77, 755-765.

Savage R.E. 1931. - The relation between the feeding of the herring off the cast coast of England and the plankton of the surrounding waters. Fishery Investigation, Ministry of Agriculture, Food and Fisheries, Series 2, 12, 1-88.

Simonson T., Lyons J. \& Kanehl P.D. 1993. - Guidelines for evaluating fish habitat in Wisconsin streams. Gen. Tech. Rep. NC-164. St. Paul, MN : U.S. Department of Agriculture, Forest Service, North Central Forest Experiment Station, 36 p.

Tippets W.E. \& Moyle P.B. 1978. - Epibenthic feeding by rainbow trout (Salmo gairdneri) in the McCloud River, California. J. Anim. Ecol., 47, 549-559.

Vignes J.C. 1998. - Relations entre la taille des juveniles de saumon atlantique (Salmo salar) et certains caractéristiques de leurs proies. Cybium, 22, 97-100.

Vinyard G.L. 1980. - Differential prey vulnerability and predator selectivity: the effects of evasive prey on sunfish (Lepomis) predation. Can. J. Aquat. Sci., 37, 2294-2299.

Vollestad L.A. \& Andersen R. 1985. - Resource partitioning of various age groups of brown trout Salmo trutta in the littoral zone of Lake Selura, Norway. Arch. Hydrobiol., 105, 177-185.

Ware D.M. 1973. - Risk of epibenthic prey to predation by rainbow trout (Salmo gairdneri). J. Fish. Res. Bd. Canada, 30, 787-797. 